\title{
Development of A Base Learning Project Model With Online Media In An Effort to Increase Learning Activities During the COVID-19 Pandemic
}

\author{
M Martiano', H Maulana \\ ${ }^{1,2}$ Department of Information System, Universitas Muhammadiyah Sumatera Utara, Medan
}

\section{Article Info}

\section{Article history:}

Received Jun 9, 2021

Revised Jul 20, 2021

Accepted Sep 11, 2021

\section{Keywords:}

Base Learning Project Model;

Online Media;

Learning Activities During;

COVID-19 Pandemic.

\begin{abstract}
Decrease in learning outcomes in operating systems courses. The decline in learning outcomes is caused by the current corona virus pandemic. Which causes face-to-face lectures to be online. Researchers use project base learning to improve learning outcomes. The application consists of 2 cycles, namely Diclus 1 which is $80.12 \%$ with the number who did not pass, namely 16 students, researcher evaluating the learning process so that in cycle 2 it increased by $83.73 \%$. With the student's who did not pass. It can be concluded that the base learning method can be used to improve learning outcomes during the COVID-19 pandemic.
\end{abstract}

This is an open access article under the CC BY-NC license.

\section{Corresponding Author:}

M Martiano,

Department of Information System,

Universitas Muhammadiyah Sumatera Utara, Indonesia

Jl. Kapten Muchtar Basri No.3, Kota Medan, Sumatera Utara 20238

Email: martiano@umsu.ac.id

\section{INTRODUCTION}

Graduate competence is a very important component that must be possessed by students to be able to compete in today's era[1]. The competencies possessed include attitudes, knowledge and skills[2]. Based on the data on the achievement of student learning outcomes, the following data are obtained:

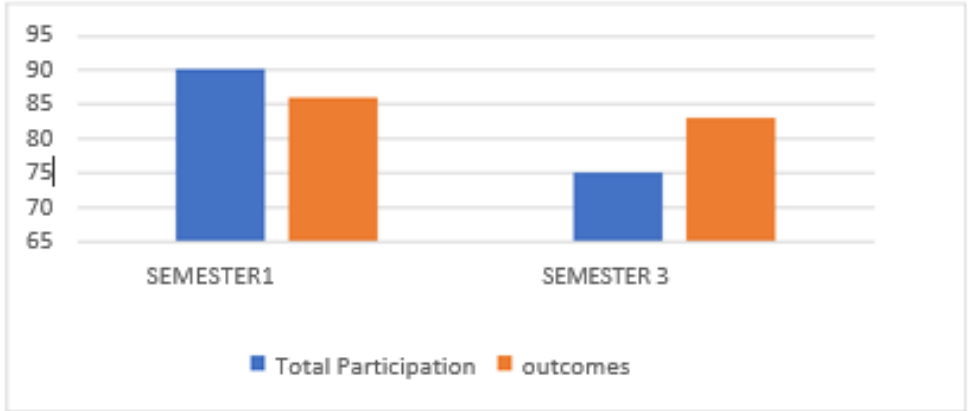

Figure 1. Student's outcomes semester 1 and 3 
It can be seen from the data above that there is a decrease in student participation and learning outcomes[3][4][5]. In 2020 semester 3 students have an interest in participation of almost $90 \%$ and learning achievement at an average of $86 \%$. Then in the new student force, this actually decreased due to the spread of the corona virus which caused the need for face-to-face restrictions, the participation rate of semester 1 students from 2020 to 2021 reached $75 \%$ and the average learning outcome was $84 \%$. From this data, there is a difference of $15 \%$ for participation and a difference of $2 \%$ for learning outcomes, plus the spread of the corona virus which is also one of the causes of the decline in student learning motivation.

Corona virus is a global pandemic that spreads so fast and no country is able to prevent the spread of the corona virus [6] the corona virus is contagious, in the sense that it spreads very quickly through networks like a disaster or flu[7]. The corona virus spreads through contact with the sufferer, unfortunately now there is no cure for the corona virus[7]. For this reason, the government in several countries has implemented a lockdown (total isolation)[8].

According to Suprijono[9], learning outcomes are patterns of actions, values, understandings, attitudes, appreciation and skills[10][11]. Furthermore, learning outcomes that become the object of class assessment are in the form of new abilities that students acquire after they participate in the teaching-learning process about certain subjects[12][13][14][15]. How strong students' motivation in learning will determine the quality and learning outcomes, therefore teachers are required to be able to encourage and increase student motivation in learning[16].

So that from the three interrelated factors, optimal learning outcomes can be achieved by each student[17][18][19]. Students have the opportunity to learn as apprenticeships where there is an increase in task complexity, knowledge and skills; The complexity of the knowledge in question is the emphasis on conceptual connectedness, and interdisciplinary learning[20]. Cooperative and collaborative learning must be able to expose students to alternative views[21]; and Measurement is authentic and becomes an inseparable part of learning activities[22].

Project-based learning is a project-based learning method that emphasizes contextual learning through complex activities[23][24][25]. There are several advantages of Project based learning, namely [26][27] making students active, because students will be charged with finding solutions to problems in the real world. With this learning method, it has the potential to be applied during this pandemic.

\section{RESEARCH METHOD}

This analysis was conducted to determine the success or failure of the actions taken in the research. It consists of 4 main components: planning (planning), acting (action), observing (observing), and reflecting (reflection) [28].

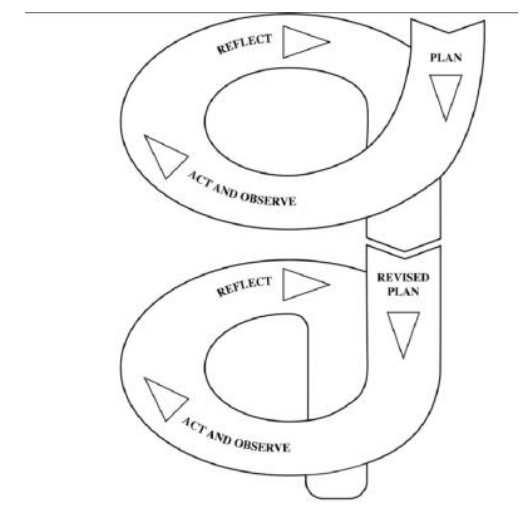

Figure 2. Action research cycle [28]

This is seen from the percentage of the success rate achieved by students. The data obtained from the field is then analyzed using qualitative data techniques. From the data analysis, 
student learning outcomes are obtained where student learning outcomes based on the instructions for implementing the teaching and learning process have individual and classical completeness, namely:

a. A student completes learning if the student has achieved a score of $65 \%$ or 6.5

b. A class is said to have completed learning if the class has $80 \%$ who have achieved more than or equal to $65 \%$ completeness.

Student learning mastery can be calculated using the formula:

Information:

$$
\mathrm{K}=\ldots \ldots \ldots . . . . \times 100 \%
$$

$\mathrm{K}=$ Completeness

$A=$ Scores that have been obtained by students

$\mathrm{B}=$ Maximum score

Criteria

$\mathrm{o} \%<80 \%=$ Students has not finished

$80 \%<100 \%=$ Students have completed their studies

Learning mastery can be calculated using the formula:

$$
\mathrm{D}=\mathrm{x} 100 \%
$$

Information:

$\mathrm{D}=$ Percentage of class that has finished studying

$\mathrm{C}=$ Number of students who have finished studying

$\mathrm{F}=$ Total number of students

The criteria produced in student learning completeness are:

Table 1. Criteria for student learning success rate

\begin{tabular}{cc}
\hline Level of success \% & Category \\
\hline $90 \%-100 \%$ & Very High \\
$80 \%-89 \%$ & High \\
$65 \%-79 \%$ & Enough \\
$55 \%-64 \%$ & Low \\
$0 \%-54 \%$ & Very low \\
\hline
\end{tabular}

\section{RESULTS AND DISCUSSIONS}

The learning process in cycle 1 went quite well by applying the project-based learning model. Learning evaluation was carried out at the second meeting. Questions are used to measure student learning outcomes in the cognitive aspect while project assignments are used to measure student learning outcomes in psychomotor aspects. The questions used have been prepared before the research is carried out. The project assignments given are different but the assignments refer to the tasks that have been given so that the level of difficulty is also evenly distributed. Data from student learning outcomes can be seen in Table 2 .

Table 2. Criteria for Student Success Rates

\begin{tabular}{cccc}
\hline Outcomes cycle 1 & \multicolumn{3}{c}{ Category } \\
\cline { 2 - 4 } & Theory & Project & Final Test \\
\hline Very High & 85 & 87 & 86 \\
Very Low & 68 & 69 & 68.5 \\
Mean & 80.12 & 82.35 & 81.23 \\
\hline
\end{tabular}




\begin{tabular}{cccc}
\hline Outcomes cycle 1 & \multicolumn{3}{c}{ Category } \\
\cline { 2 - 4 } & Theory & Project & Final Test \\
\hline Passed Student & 20 & 24 & \\
Pass Percentage & $58.82 \%$ & $64.86 \%$ & $61.84 \%$ \\
\hline
\end{tabular}

Based on the results of the reflection there are problems that can be seen from Table 3 .

Table 3. Criteria for Student Learning Success Rates

Observation Reflections

1. There are still some students who are less 1 . Students must be active in the active at the time of this zoom because they camera, and dress coders must use have a lying learning position, this makes polite shirts and clothes, and must concentration decrease not lie down or lie down.

2. students are still wrong in making 2.Mahasiswa wajib membuat presentations because students do not focus on rangkuman dan wajib taking notes dikumpulkan melalui elerning

3. Don't ask when the presentation starts. 3 3. Lecturers must choose students who will be prepared to ask questions

Based on the results of observations on student learning activities in cycle 2 , it shows that the learning activities carried out by students have increased. The results of observations show the average value of student learning activities in the cycle as shown in the table below:

Table 4. Student Learning Outcomes Cycle II

\begin{tabular}{cccc}
\hline Hasil Belajar Siklus 2 & \multicolumn{3}{c}{ Kategori } \\
\cline { 2 - 4 } & Teori & Proyek & Nilai Akhir \\
\hline Very High & 90 & 92 & 91 \\
Very Low & 81 & 80 & 80.5 \\
Mean & 83.12 & 86.35 & 84.78 \\
Passed Student & 36 & 36 & \\
Pass Percentage & $100 \%$ & $100 \%$ & $100 \%$ \\
\hline
\end{tabular}

\section{CONCLUSION}

Student learning activity is one of the variables observed in the implementation of the project-based learning model. Cycle 1 shows the average percentage of student learning activities of $80.12 \%$. From these results have met the criteria for the success of the action so that it can be continued in the next cycle. The average percentage of student learning activities in cycle 2 reached $83.73 \%$. The increase in student learning activities from cycle 1 to cycle 2 was $3.61 \%$. The results can be seen from the image below:

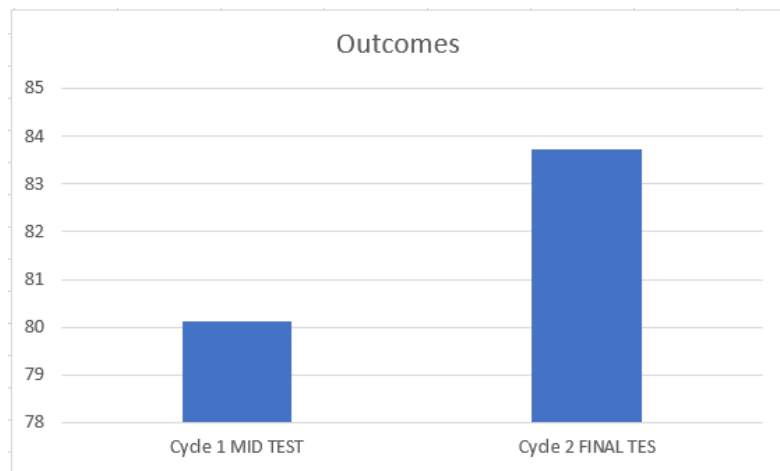

Figure 3. Student's outcomes cycle 1 and 3 
In detail, it can be seen the increase in student learning activities in each indicator of learning outcomes in the picture below:

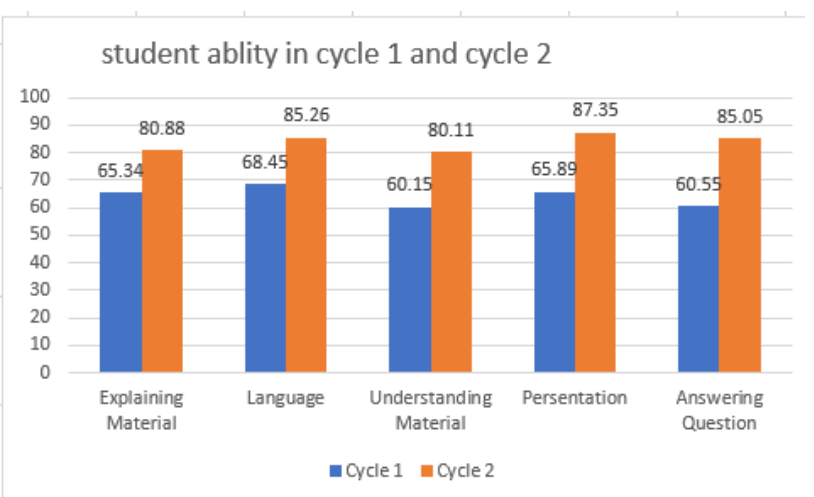

Figure 4. Student's ablity in cycle 1 and 2

From the data above, the researchers compared the above competencies through direct assessment of student performance, it can be concluded that students' abilities increased between cycle 1 and cycle 2.

\section{ACKNOWLEDGEMENTS}

Praise and gratitude we pray to the presence of Allah SWT the Almighty for His gifts and blessings, and the Prophet Muhammad SAW, thanks to his saga, we were able to complete a progress report on "Development of Project Based Learning Learning Models Through Online Media Efforts to Improve Motivation and Learning Outcomes in Courses Operating system ". This Progress Report was prepared to meet the requirements of UMS internal research in 2021. The researcher took this title with the aim of developing interesting teaching methods for students during the corona virus 19 pandemic. The aim was to improve teaching services in the computer science faculty, especially the information systems study program. The preparation of this paper could not have been completed without the support and participation of all parties. For that, allow us to express our gratitude to the rector of the University of Muhammadiyah North Sumatra. We realize that in compiling this progress report there are still many shortcomings, therefore criticism and suggestions are needed for the perfection of this paper in the future.

\section{REFERENCES}

[1] D. S. Adeleke and E. N. Emeahara, "RELATIONSHIP BETWEEN INFORMATION LITERACY AND USE OF ELECTRONIC INFORMATION RESOURCES BY POSTGRADUATE STUDENTS OF THE UNIVERSITY OF IBADAN.," Libr. Philos. Pract., 2016.

[2] R. Hämäläinen, K. Nissinen, J. Mannonen, J. Lämsä, K. Leino, and M. Taajamo, "Understanding teaching professionals' digital competence: What do PIAAC and TALIS reveal about technology-related skills, attitudes, and knowledge?," Comput. Human Behav., vol. 117, p. 106672, 2021.

[3] Y. Bergner, D. Kerr, and D. E. Pritchard, "Methodological Challenges in the Analysis of MOOC Data for Exploring the Relationship between Discussion Forum Views and Learning Outcomes.," Int. Educ. data Min. Soc., 2015.

[4] G. Barata, S. Gama, J. Jorge, and D. Gonçalves, "Improving participation and learning with gamification," in Proceedings of the First International Conference on gameful design, research, and applications, 2013, pp. 10-17.

[5] B. Zheng and Y. Zhang, "Self-regulated learning: the effect on medical student learning outcomes in a flipped classroom environment," BMC Med. Educ., vol. 20, no. 1, pp. 1-7, 2020.

[6] K. M. Agarwal, S. Mohapatra, P. Sharma, S. Sharma, D. Bhatia, and A. Mishra, "Study and overview of the novel corona virus disease (COVID-19)," Sensors Int., p. 100037, 2020.

[7] N. Mona, “Contagion mechanism on social network (Bullying On Teenage Peer Group)," Soc. Sci., vol. 11, no. 19, pp. 4599-4602, 2016. 
[8] J. Savulescu and J. Cameron, "Why lockdown of the elderly is not ageist and why levelling down equality is wrong," J. Med. Ethics, vol. 46, no. 11, pp. 717-721, 2020.

[9] A. Suprijono, Cooperative learning: teori E aplikasi PAIKEM. Pustaka Pelajar, 2009.

[10] O. P. Wijaya and I. Bukhori, "Effect of Learning Motivation, Family Factor, School Factor, and Community Factor on Student Learning Outcomes on Productive Subjects," JPBM (Jurnal Pendidik. Bisnis dan Manajemen), vol. 3, no. 3, pp. 192-202, 2017.

[11] M. Storksdieck, K. Ellenbogen, and J. E. Heimlich, "Changing minds? Reassessing outcomes in freechoice environmental education," Environ. Educ. Res., vol. 11, no. 3, pp. 353-369, 2005.

[12] R. B. Barr and J. Tagg, "From teaching to learning-A new paradigm for undergraduate education," Chang. Mag. High. Learn., vol. 27, no. 6, pp. 12-26, 1995.

[13] D. D. Serbessa, "Tension between traditional and modern teaching-learning approaches in Ethiopian primary schools," J. Int. Coop. Educ., vol. 9, no. 1, pp. 123-140, 2006.

[14] B. L. Gleason et al., "An active-learning strategies primer for achieving ability-based educational outcomes," Am. J. Pharm. Educ., vol. 75, no. 9, 2011.

[15] L. Shepard, "The role of classroom assessment in teaching and learning," 2001.

[16] J. Meece and W. McColskey, "Improving Student Motivation. A Guide for Teachers and School Improvement Teams.," 1997.

[17] I. Veriansyah, Sarwono, and M. G. Rindarjono, "Hubungan Tingkat Intelegensi (IQ) Dan Motivasi Belajar Geografi Dengan Hasil Belajar Siswa Kelas X Sekolah Menengah Atas Singkawang Kota Tahun Ajaran 2016/2017," J. GeoEco, vol. 4, no. 1, pp. 41-50, 2018.

[18] R. Ananda, "The effect of learning strategies and learning independence on learning outcomes in learning evaluation subject," Int. J. Lang. Res. Educ. Stud., vol. 3, no. 3, pp. 340-350, 2019.

[19] K. Kraiger, J. K. Ford, and E. Salas, "Application of cognitive, skill-based, and affective theories of learning outcomes to new methods of training evaluation.," J. Appl. Psychol., vol. 78, no. 2, p. 311, 1993.

[20] S. Schaal, F. X. Bogner, and R. Girwidz, "Concept mapping assessment of media assisted learning in interdisciplinary science education," Res. Sci. Educ., vol. 40, no. 3, pp. 339-352, 2010.

[21] T. Panitz and P. Panitz, "Encouraging the use of collaborative learning in higher education," Univ. Teach. Int. Perspect., pp. 161-201, 1998.

[22] W. Kamdi, "Pembelajaran berbasis proyek: model potensial untuk peningkatan mutu pembelajaran," $J$. Gentengkali, Malang, 2007.

[23] I. Rahmania, "Project based learning (PjBL) learning model with STEM approach in natural science learning for the 21st century,” Budapest Int. Res. Critics Inst. Humanit. Soc. Sci., vol. 4, no. 1, pp. 1161-1167, 2021.

[24] N. Wijayati, W. Sumarni, and S. Supanti, "Improving student creative thinking skills through project based learning," KnE Soc. Sci., pp. 408-421, 2019.

[25] E. Murniarti, "Penerapan Metode Project Based Learning," J. Educ., vol. 3, no. 2, pp. 369-380, 2017.

[26] J. S. Krajcik and P. C. Blumenfeld, Project-based learning. na, 2006.

[27] J. W. Thomas, "A review of research on project-based learning." California, 2000.

[28] Maestrini, V., Luzzini, D., Shani, A. B. R., \& Canterino, F. (2016). The action research cycle reloaded: Conducting action research across buyer-supplier relationships. Journal of Purchasing and Supply Management, 22(4), 289-298. 